\title{
Optimization of Concrete Cost Based On Its Elastic Modulus
}

\author{
Onwuka, D.O ${ }^{\mathrm{a}}$, Egbulonu, R.B.A ${ }^{\mathrm{b}}$ and Onwuka, S.U ${ }^{\mathrm{c}}$ \\ ${ }^{a, b}$ Civil Enineering, Federal University of Technology, Owerri, Nigeria. \\ ${ }^{c}$ Project management Technology, Owerri, Nigeria.
}

\begin{abstract}
In order to obtain concrete with a desired elastic modulus, E, at minimum cost, it is necessary to carry out optimization of concrete mixtures. Effectively and efficiently optimized concrete mixtures, usually have better properties, satisfy intended use and minimize costs. In this work, the cost of concrete mixtures based on its elastic modulus, E, is optimized using Osadebe's optimization Method. The resulting optimization model can be used to estimate the cost of concrete when the elastic modulus, E, is specified. Conversely, the model can be used to determine the elastic modulus, E, obtainable from concrete mixture of a given cost. In addition, it can be used to determine the optimum concrete mix and cost when given the desired elastic modulus, E. Fluctuations in market prices can be accommodated by multiplying the base prices of constituent materials with a price fluctuation factor $(P F F)$. The predicted costs compare favourable with the values obtained from the market survey. The optimization model was tested for adequacy using statistical tools and found to be adequate.
\end{abstract}

Keywords: Optimization, Costs, Concrete Mixtures, Elastic Modulus, Osadebe'sTheory, Optimization Method.

\section{Introduction}

Today, concrete is the most widely used construction material. Some of its notable properties are workability of the fresh concrete are compressive strength, elastic modulus, durability and thermal characteristics of hardened concrete. A knowledge of its modulus of elasticity, E, is necessary in the analysis and design of structural concrete members. The production of concrete using conventional mix design methods, are well known and documented. These conventional methods of concrete mix design used to obtain concrete of desired modulus of elasticity, MOE, involve several trial mixes with their attendant waste of time, materials and labour.

However concrete can be optimized to meet a number of performance criteria simultaneously at minimum cost. Majid (1974) defined optimization as a process that seeks for a maximum value for a function of severable variables while at the same time satisfying a number of imposed requirements. Although, optimization methods require commitment of time and money upfront, they have the potential to save money during production (Simon et al, 1997). In this article, an optimization approach by Osadebe (2003) is adopted and used for the formulation of an optimization model for predicting the cost of concrete on the basis of its modulus of elasticity. To achieve this, experiments were carried out and the results used to develop the final optimization model based on the Osadebe's optimization method.

\subsection{Osadebe Optimization Method}

\section{Methods}

Osadebe (2003) assumed that a regression function, $\mathrm{F}_{(\mathrm{Z})}$, is continuous and differentiable with respect to its variables, $\mathrm{Z}_{\mathrm{i}}$. By making use of Taylor's series, the response function, could be expanded in the neighbourhood of a chosen point, $Z^{(0)}$

$$
F(z)={\underset{\mathrm{a}}{\mathrm{a}}}_{m=0}^{¥} \frac{f_{(z)^{(0)}}^{(m)}}{m !}\left(z_{i}-z^{(0)}\right)^{m}
$$

Expanding Eqn (1) up to the second order gives:

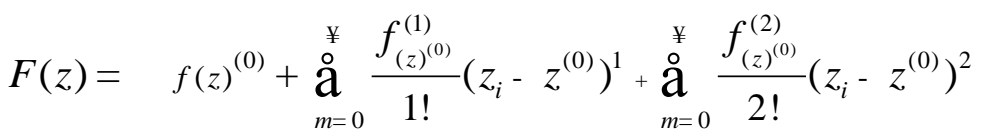

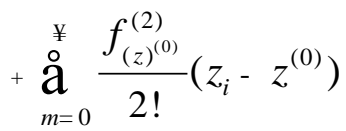

where $\mathrm{m}=$ degree of polynomial of the response function

$$
\text { and } \quad 0 \leq \mathrm{i} \leq 4
$$

Assuming $\mathrm{Z}_{\mathrm{i}}$ is the fractional portion and $\mathrm{S}_{\mathrm{i}}$, the actual portion of the mixture component, then the total quantity of concrete, $\mathrm{S}$, for a four-component mixture, is given by 


$$
\mathrm{S}=\stackrel{\circ}{\mathrm{a}} S_{i}
$$

Thus,

$$
\mathrm{S}=\mathrm{S}_{1}+\mathrm{S}_{2}+\mathrm{S}_{3}+\mathrm{S}_{4}
$$

If $1 \mathrm{~m}^{3}$ of concrete is required, dividing both sides of Eqn (4) by $\mathrm{S}$ yields:

$$
\mathrm{S} / \mathrm{S}=\mathrm{S}_{1} / \mathrm{S}+\mathrm{S}_{2} / \mathrm{S}+\mathrm{S}_{3} / \mathrm{S}+\mathrm{S}_{4} / \mathrm{S}
$$

Let $\mathrm{S}_{\mathrm{i}} / \mathrm{S}=\mathrm{Z}_{\mathrm{i}}$

Then,

$$
1=Z_{1}+Z_{2}+Z_{3}+Z_{4}
$$

This can be written in compact form as :

$$
\text { å } Z=1
$$

Assuming the point $\mathrm{Z}_{0}$ is taken as the origin, it implies that

$$
z^{(0)}=0
$$

Thus

$$
z_{1}^{0}=z_{2}^{0}=z_{3}^{0}=z_{4}^{0}
$$

Let,

$$
\begin{aligned}
b_{0} & =\mathrm{F}(0) \quad \ldots . \\
b_{i} & =\frac{\prod F(0)}{\llbracket Z_{i}} \\
b_{i j} & =\frac{\prod F^{2}(0)}{\prod Z_{i} \rrbracket Z_{j}} \\
b_{i i} & =\frac{\prod F^{2}(0)}{\llbracket Z_{i}^{2}}
\end{aligned}
$$

Substituting Eqns (11)-(14) into Eqn(2) yields Eqn(15) for 4-component mixture:

$$
\mathrm{F}(\mathrm{z})=b_{0}+\stackrel{\circ}{\mathrm{a}}_{i=1}^{4} b_{i} Z_{i}+\underset{i=1, j=1}{\stackrel{\circ}{\mathrm{a}}} b_{i j} Z_{i} Z_{j}+\stackrel{\circ}{\mathrm{a}}_{i=1}^{4} b_{i i} z_{i}{ }^{2}
$$

Multiplying Eqn (7) by $b_{0}$ gives:

$b_{0}=b_{0} Z_{1}+b_{0} Z_{2}+b_{0} Z_{3}+b_{0} Z_{4}$

Multiplying Eqn (7) successfully by $\mathrm{Z}_{1}, \mathrm{Z}_{2}, \mathrm{Z}_{3}$ and $\mathrm{Z}_{4}$ yields respectively:

$$
\begin{aligned}
& Z_{1}=Z_{1}^{2}+Z_{1} Z_{2}+Z_{1} Z_{3}+Z_{1} Z_{4} \\
& Z_{2}=Z_{1} Z_{2}+Z_{2}^{2}+Z_{2} Z_{3}+Z_{2} Z_{4} \\
& Z_{3}=Z_{1} Z_{3}+Z_{2} Z_{3}+Z_{3}^{2}+Z_{3} Z_{4} \\
& Z_{4}=Z_{1} Z_{4}+Z_{2} Z_{4}+Z_{3} Z_{4}+Z_{4}^{2}
\end{aligned}
$$

Rearranging Eqns (17)-(20) gives:

$$
\begin{gathered}
Z_{1}{ }^{2}=Z_{1}-Z_{1} Z_{2}-Z_{1} Z_{3}-Z_{1} Z_{4} \ldots \\
Z_{2}{ }^{2}=Z_{2}-Z_{1} Z_{2}-Z_{2} Z_{3}-Z_{2} Z_{4} \\
Z_{3}{ }^{2}=Z_{3}-Z_{1} Z_{3}-Z_{2} Z_{3}-Z_{3} Z_{4} \\
Z_{4}{ }^{2}=Z_{4}-Z_{1} Z_{4}-Z_{2} Z_{4}-Z_{3} Z_{4}
\end{gathered}
$$

Substituting Eqns (21) - (24) into Eqn (15) yields Eqn(25)

$$
\begin{aligned}
\mathrm{Y}=b_{0} Z_{1}+b_{0} & Z_{2}+b_{0} Z_{3}+b_{0} Z_{4}+b_{1} Z_{1}+b_{2} Z_{2}+b_{3} Z_{3}+b_{4} Z_{4} \\
& +b_{12} Z_{1} Z_{2}+b_{13} Z_{1} Z_{3}+b_{14} Z_{1} Z_{4}+b_{23} Z_{2} Z_{3}+b_{24} Z_{2} Z_{4}+b_{34} Z_{3} Z_{4} \\
& +b_{11}\left(Z_{1}-Z_{1} Z_{2}-Z_{1} Z_{3}-Z_{1} Z_{4}\right)+b_{22}\left(Z_{2}-Z_{1} Z_{2}-Z_{2} Z_{3}-Z_{2} Z_{4}\right) \\
& +b_{33}\left(Z_{3}-Z_{1} Z_{3}-Z_{2} Z_{3}-Z_{3} Z_{4}\right)+b_{44}\left(Z_{4}-Z_{1} Z_{4}-Z_{2} Z_{4}-Z_{3} Z_{4}\right)
\end{aligned}
$$

Factorizing Eqn (25 gives:

$\mathrm{Y}=\left(b_{0}+b_{1}+b_{11}\right) Z_{1}+\left(b_{0}+b_{2}+b_{22}\right) Z_{2}+\left(b_{0}+b_{3}+b_{33}\right) Z_{3}+\left(b_{0}+b_{4}+b_{44}\right) Z_{4}$ 


$$
\begin{aligned}
& +\left(b_{12}-b_{11}-b_{22}\right) Z_{1} Z_{2}+\left(b_{13}-b_{11}-b_{33}\right) Z_{1} Z_{3}+\left(b_{14}-b_{11}-b_{44}\right) Z_{1} Z_{4} \\
& +\left(b_{23}-b_{22}-b_{33}\right) Z_{2} Z_{3}+\left(b_{24}-b_{22}-b_{44}\right) Z_{2} Z_{4}+\left(b_{34}-b_{33}-b_{44}\right) Z_{3} Z_{4}
\end{aligned}
$$

Since the summation of constants gives another constant, let

$$
\text { and } \quad \begin{array}{ll} 
& a_{i}=b_{0}+b_{i}+b_{i i} \\
& a_{i j}=b_{i j}-b_{i i}+b_{j j}
\end{array}
$$

Then, substituting Eqns (27) and (28) into Eqn (26) yields:

$$
\begin{aligned}
\mathrm{Y}= & a_{1} z_{1}+a_{2} z_{2}+a_{3} z_{3}+a_{4} z_{4}+a_{12} z_{1} z_{2}+a_{13} z_{1} z_{3}+a_{14} z_{1} z_{4} \\
& +a_{23} z_{2} z_{3}+a_{24} z_{2} z_{4}+a_{34} z_{3} z_{4} \ldots \ldots \ldots \ldots \ldots \ldots \ldots \ldots \ldots \ldots \ldots \ldots \ldots \ldots \ldots \ldots \ldots \ldots \ldots \ldots \ldots \ldots
\end{aligned}
$$

In compact form, Eqn (29) becomes:

$$
\mathrm{Y}=\stackrel{\AA^{4}}{\mathrm{a}} a_{i} z_{i}+\stackrel{\circ}{\mathrm{a}}_{i=1}^{4} \stackrel{\circ}{\mathrm{a}}_{j=1}^{4} a_{i j} z_{i} z_{j}
$$

In Eqn(30), $\mathrm{Y}$ is the response function at any point of observation, $\mathrm{z}_{\mathrm{i}}$ and $\mathrm{z}_{\mathrm{j}}$ are the predictors, and $a_{i}$ and $a_{j}$ are the coefficients of the regression equation.

Putting Eqn(30) in a matrix form gives:

$$
\left[\mathrm{Y}^{(\mathrm{n})}\right]=\quad\left[\mathrm{Z}^{(\mathrm{n})}\right][a] \ldots
$$

In expanded form, Eqn(31) becomes

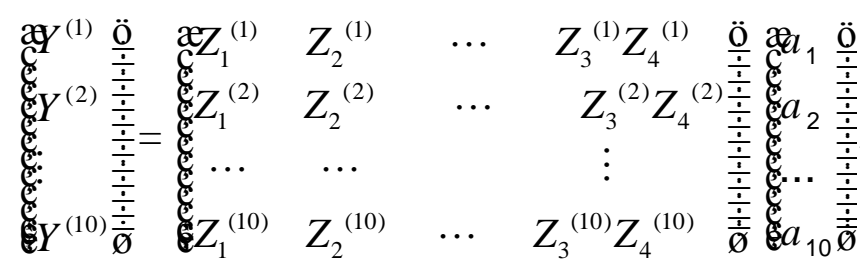

Rearranging, Eqn (32) yields

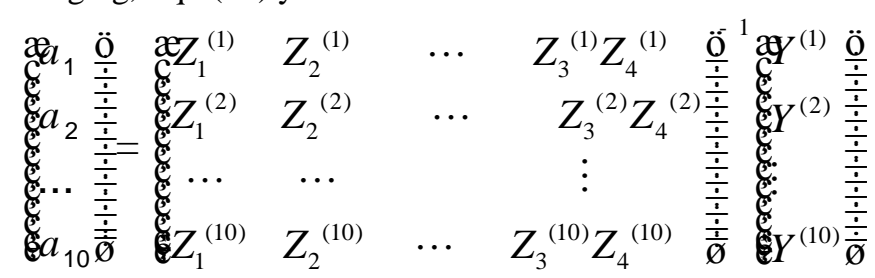

Putting Eqn(32) in a compact form gives:

$$
[a]=\left[\mathrm{Z}^{(\mathrm{n})}\right]^{-1}\left[\mathrm{Y}^{(\mathrm{n})}\right]
$$$$
\text { where }
$$

$\left[\mathrm{Y}^{(\mathrm{n})}\right]=$ matrix of responses function determined from laboratory tests.

$\left[\mathrm{Z}^{(\mathrm{n})}\right]=$ matrix of fractional portions obtained from matrix of actual portion.

$[\alpha]=$ matrix of coefficients of the regression function'

It should be noted that fractional portion, $\mathrm{Z}_{\mathrm{i}}$, is the ratio of the actual portions, $\mathrm{S}_{\mathrm{i}}$, to the total quantity of concrete, $S$. Thus, the values of the fractional portions, $Z_{\mathrm{i}}$, is obtained from the values of actual portions, $S_{\mathrm{i}}$, and presented in Table 1. The $Z^{(\mathrm{n})}$ values were used for developing the $Z^{(\mathrm{n})}$ matrix and the inverse $Z^{(\mathrm{n})}$ matrix given in Tables 2 and 3 respectively.

\section{2experimental Method}

Tests were conducted in the laboratory to determine the values of the response, $\mathrm{Y}_{\mathrm{i}}$, required to determine the final response function for predicting the elastic modulus of concrete. In all, fourteen mix ratios were used for producing 28 cylindrical concrete specimen measuring $100 \mathrm{~mm}$ in diameter and $200 \mathrm{~mm}$ in depth. Four out of the fourteen mix ratios were used as control mix ratios for testing the adequacy of the regression response function developed in this work. The cylindrical concrete specimen were produced from Dangote cement, a brand of Portland cement conforming to BS 12 (1978) specifications, river sand that fell within zone 2 of BS 882 grading zone, crushed granite of maximum size conforming to BS 882 and B.S 812 (1983) and portable water. The concrete cylinders were cast, cured in water for 28 days and then, tested in a universal testing machine in accordance with the specifications of BS 1881 (1983). The results of the laboratory tests are presented in Table 4 


\subsection{Costing Of Materials}

This section is concerned with the determination of the cheapest of all the concrete mixes that will yield a particular modulus of elasticity. Knowledge of current market price of the constituent (building) materials is very essential in the determination of the total costs of various concrete mixes. The unit prices of these constituent materials are defined as follows:
$\mathrm{N} \mathrm{w}=$ cost of water per $\mathrm{kg}$
$\# \mathrm{c} \quad=\quad$ cost of cement per $\mathrm{kg}$
$\# \mathrm{k} \quad=\quad$ cost of sand per $\mathrm{kg}$
$\# \mathrm{p} \quad=\quad$ cost of coarse aggregate per $\mathrm{kg}$

Calculation of Quantities of concrete constituents.

The predictors, $\mathrm{Z}_{\mathrm{i}}$, are determined from the response function i.e Eqn (29) for predicting the possible combinations of the proportions of the concrete constituents for a desired modulus of elasticity.

It will be recalled that for $1 \mathrm{~m}^{3}$ of concrete,

$\mathrm{Z}_{1}+\mathrm{Z}_{2}+\mathrm{Z}_{3}+\mathrm{Z}_{4}=1$

This can be rewritten in a compact form as follows:

$$
\stackrel{\varliminf}{\mathrm{a}}_{i=1}^{4} Z_{i}=1
$$

But, the total weight of $1 \mathrm{~m}^{3}$ of concrete $=2400 \mathrm{~kg}$

Therefore,

Quantity of water $=\frac{z_{1}}{\stackrel{\circ}{\mathrm{a}} z} * 2400 \mathrm{Kg}$.

where $\mathrm{z}_{1}=$ proportion of water in $1 \mathrm{~m} 3$ of concrete.

Quantity of cement $=\frac{Z_{2}}{2} * 2400 \mathrm{Kg}$

å $z$

where $\mathrm{z}_{2}=$ proportion of cement in $1 \mathrm{~m} 3$ of concrete.

Quantity of sand $=\frac{z_{3}}{2400 \mathrm{Kg}}$

\section{å $z$}

where $z_{3}=$ proportion of sand in $1 \mathrm{~m} 3$ of concrete.

Quantity of coarse aggregate $=\frac{z_{4}}{g} * 2400 \mathrm{Kg}$

$$
\text { å z }
$$

where $z_{1}=$ proportion of coarse aggregate in $1 \mathrm{~m} 3$ of concrete.

\section{COSTS OF CONCRETE}

Cost of water $=\frac{z_{1}}{\stackrel{\circ}{a} z} * 2400 * \mathrm{w}$.

Cost of cement $=\frac{z_{2}}{\stackrel{\circ}{\mathrm{a}} z} * 2400 * \mathrm{c}$

Cost of sand $=\frac{z_{3}}{\stackrel{\circ}{\mathrm{a}} z} * 2400 * \mathrm{k}$ 
Cost of coarse aggregate $=\frac{z_{4}}{2400 * \mathrm{p}}$

$$
\text { å } z
$$

Therefore, the total cost of concrete is obtained by summing up the costs of its constituents as follows:

Total cost of concrete, $\mathrm{C}_{\mathrm{t}}=($ cost of water + cost of cement + cost of sand + cost of coarse aggregate).

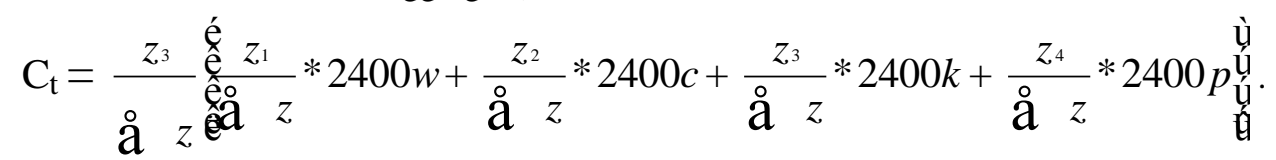

Simplifying Eqn(4) gives:

$$
\begin{aligned}
& C_{t}=\frac{2400}{4}\left[z_{1} w+z_{2} c+z_{3} k+z_{4} p\right] \\
& \text { å z }
\end{aligned}
$$

III. Results And Analysis

\begin{tabular}{|c|c|c|c|c|c|}
\hline $\begin{array}{c}\text { Exp } \\
\text { No }\end{array}$ & $\begin{array}{c}\text { Mix ratios } \\
\text { w/c }: c: \text { F.A:C.A }\end{array}$ & Replciates & $\begin{array}{c}\text { Response } \\
\text { symbol }\end{array}$ & $\begin{array}{c}\text { MOE } \\
\left(\mathbf{N} / \mathbf{m m}^{2}\right)\end{array}$ & $\begin{array}{l}\text { Average MOE } \\
\qquad\left(\mathrm{N} / \mathbf{m m}^{2}\right)\end{array}$ \\
\hline \multirow[t]{2}{*}{1} & \multirow[t]{2}{*}{$0.5: 1: 1.5: 3$} & $1 \mathrm{~A}$ & $\mathrm{Y}_{1}$ & 40.20 & \multirow[t]{2}{*}{41.30} \\
\hline & & 1B & $\mathrm{Y}_{1}$ & 42.42 & \\
\hline \multirow[t]{2}{*}{2} & \multirow{2}{*}{$0.55: 1: 2: 3$} & $2 \mathrm{~A}$ & $\mathrm{Y}_{2}$ & 55.03 & \multirow{2}{*}{50.04} \\
\hline & & $2 \mathrm{~B}$ & $\mathrm{Y}_{2}$ & 45.05 & \\
\hline \multirow[t]{2}{*}{3} & \multirow[t]{2}{*}{$0.6: 1: 2: 4$} & $3 \mathrm{~A}$ & $\mathrm{Y}_{3}$ & 24.97 & \multirow[t]{2}{*}{25.21} \\
\hline & & $3 \mathrm{~B}$ & $\mathrm{Y}_{3}$ & 25.45 & \\
\hline \multirow[t]{2}{*}{4} & \multirow[t]{2}{*}{$0.65: 1: 3: 5$} & $4 \mathrm{~A}$ & $\mathrm{Y}_{4}$ & 19.39 & \multirow[t]{2}{*}{19.24} \\
\hline & & $4 \mathrm{~B}$ & $\mathrm{Y}_{4}$ & 19.09 & \\
\hline \multirow[t]{2}{*}{5} & \multirow[t]{2}{*}{$0.525: 1: 1.5: 2.25$} & $5 \mathrm{~A}$ & $\mathrm{Y}_{5}$ & 22.13 & \multirow[t]{2}{*}{21.78} \\
\hline & & $5 B$ & $\mathrm{Y}_{5}$ & 21.43 & \\
\hline \multirow[t]{2}{*}{6} & \multirow[t]{2}{*}{$0.55: 1: 1.5: 2.75$} & $6 \mathrm{~A}$ & $\mathrm{Y}_{6}$ & 25.43 & \multirow[t]{2}{*}{26.10} \\
\hline & & $6 \mathrm{~B}$ & $\mathrm{Y}_{6}$ & 26.77 & \\
\hline \multirow[t]{2}{*}{7} & \multirow[t]{2}{*}{$0.575: 1: 2: 3.25$} & $7 \mathrm{~A}$ & $\mathrm{Y}_{7}$ & 34.20 & \multirow[t]{2}{*}{35.80} \\
\hline & & $7 \mathrm{~B}$ & $\mathrm{Y}_{7}$ & 37.40 & \\
\hline \multirow[t]{2}{*}{8} & \multirow[t]{2}{*}{$0.575: 1: 2: 3.5$} & $8 \mathrm{~A}$ & $\mathrm{Y}_{8}$ & 25.54 & \multirow[t]{2}{*}{23.68} \\
\hline & & $8 \mathrm{~B}$ & $Y_{8}$ & 21.82 & \\
\hline \multirow[t]{2}{*}{9} & \multirow[t]{2}{*}{$0.6: 1: 2.5: 4$} & $9 \mathrm{~A}$ & $\mathrm{Y}_{9}$ & 28.90 & \multirow[t]{2}{*}{28.15} \\
\hline & & 9B & $\mathrm{Y}_{9}$ & 27.40 & \\
\hline \multirow[t]{2}{*}{10} & \multirow[t]{2}{*}{$0.625: 1: 2.5: 4.5$} & $10 \mathrm{~A}$ & $Y_{10}$ & 26.36 & \multirow[t]{2}{*}{25.79} \\
\hline & & 10B & $Y_{10}$ & 25.22 & \\
\hline \multirow[t]{2}{*}{11} & \multirow[t]{2}{*}{$0.575: 1: 2: 3.375$} & $11 \mathrm{~A}$ & $\mathrm{Y}_{11}$ & 23.20 & 27.08 \\
\hline & & $11 \mathrm{~B}$ & $Y_{11}$ & 22.76 & \\
\hline 12 & $0.5875: 1: 2.25: 3.625$ & $12 \mathrm{~A}$ & $\mathrm{Y}_{12}$ & 26.58 & 23.93 \\
\hline & & $12 \mathrm{~B}$ & $Y_{12}$ & 26.92 & \\
\hline 13 & $0.625: 1: 2.75: 4.5$ & $13 \mathrm{~A}$ & $\mathrm{Y}_{13}$ & 23.35 & 22.71 \\
\hline & & $13 \mathrm{~B}$ & $Y_{13}$ & 22.41 & \\
\hline 14 & $0.54: 1: 1.6: 2.6$ & $14 \mathrm{~A}$ & $Y_{14}$ & 18.61 & 19.69 \\
\hline & & 14B & $\mathrm{Y}_{14}$ & 18.97 & \\
\hline
\end{tabular}

The results of the experimental tests are given in Table 4

Table 4.: Experimental results

where $\mathrm{w} / \mathrm{c}=$ water-cement ratio
$\mathrm{C}=$ Cement
F.A. = Fine Aggregate,
C.A $=$ Coarse Aggregate 
$\mathrm{MOE}=$ modulus of Elasticity

4.1 Determination Of The Regression Function For Elastic Modulus. Substituting the values of obtained from the test results (given in Table 4) into Eqn (33) yields the following coefficients, $\alpha$

$$
\left[\begin{array}{l}
\alpha_{1} \\
\alpha_{2} \\
\alpha_{3} \\
\alpha_{4} \\
\alpha_{5} \\
\alpha_{6} \\
\alpha_{7} \\
\alpha_{8} \\
\alpha_{9} \\
\alpha_{10}
\end{array}\right]=\left[\begin{array}{l}
5351667.6400 \\
888151.9143 \\
1835.219102 \\
2392.479301 \\
-10609392.05 \\
-5791804.077 \\
-5620199.635 \\
-699734.4294 \\
-786415.528 \\
12085.08274
\end{array}\right]
$$

And substituting the values of these coefficients into Eqn (29) gives:

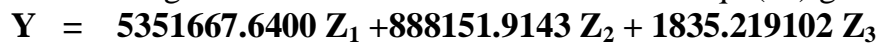

$$
\begin{aligned}
& +2392.479301 Z_{4}-10609392.05 Z_{1} Z_{2}-5791804.077 Z_{1} Z_{3} \\
& \text {-5620199.635 } Z_{1} Z_{4}-699734.4294 Z_{2} Z_{3}-786415.528 Z_{2} Z_{4} \\
& +\mathbf{1 2 0 8 5 . 0 8 2 7 4 ~} \mathrm{Z}_{3} \mathrm{Z}_{4}
\end{aligned}
$$

The Eqn (49), is the final Osadebe's regression function for optimizing the Modulus of Elasticity of a 28 day concrete.

\subsection{Test Of Goodness Of Fit Of Osadebe's Regression Function.}

(a) Determination of Replication Error.

The variation of replicates, $S_{\mathrm{y}}$ at any arbitrary point of observation arising from instruments, tools and weather variation, is determined using Eqn (50)

$$
\begin{aligned}
& \mathrm{S}_{\mathrm{y}}{ }^{2}=\frac{1}{V_{e}} \stackrel{\mathrm{a}}{ } S_{i}^{2}
\end{aligned}
$$

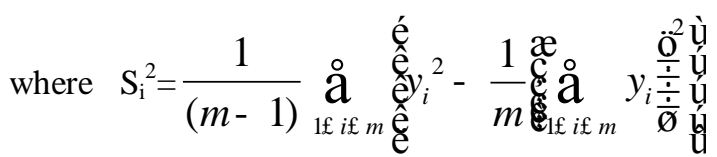

$$
\begin{aligned}
& \mathrm{m}_{\mathrm{i}}-1=\text { degree of freedom } \\
& \mathrm{y}_{\mathrm{i}} \quad=\text { value of responses at any point } \\
& \bar{y}_{i}=\text { mean of responses }
\end{aligned}
$$

\begin{tabular}{|c|c|c|c|c|c|c|c|}
\hline $\begin{array}{l}\text { Exp } \\
\text { No }\end{array}$ & Replicate & $\begin{array}{l}\text { Response } \\
\text { symbol }\end{array}$ & $\begin{array}{l}\text { MOE, } \\
\left(\mathrm{N} / \mathbf{m m}^{2}\right.\end{array}$ & $\stackrel{\mathrm{a}}{r=1}_{r}^{m_{i}} y_{r}$ & $\bar{y}$ & ${\stackrel{\stackrel{\varliminf}{m}}{m_{i}}}_{r=1}^{2}$ & $S_{i}^{2}$ \\
\hline 1 & $\begin{array}{l}1 \mathrm{~A} \\
1 \mathrm{~B}\end{array}$ & $\mathrm{Y}_{1}$ & $\begin{array}{l}40.20 \\
42.42 \\
\end{array}$ & 82.62 & 41.30 & 3415.50 & 2.4642 \\
\hline
\end{tabular}

Thus, random error is given by:

$$
\mathrm{S}_{\mathrm{y}}=\frac{1}{V_{e}} \sqrt{S_{y}^{2}}
$$

The replication variance and random error computations are carried out and summarized in Table 5.

Table 5: Computations of Standard Error of Replicates and Replication Variance of Modulus of Elasticity of Test Results. 
Optimization Of Concrete Cost Based On Its Elastic Modulus

\begin{tabular}{|c|c|c|c|c|c|c|c|}
\hline 2 & $\begin{array}{l}2 \mathrm{~A} \\
2 \mathrm{~B}\end{array}$ & $\mathrm{Y}_{2}$ & $\begin{array}{l}55.03 \\
45.05\end{array}$ & 100.08 & 50.04 & 5057.00 & 49.8002 \\
\hline 3 & $\begin{array}{l}3 \mathrm{~A} \\
3 \mathrm{~B}\end{array}$ & $\mathrm{Y}_{3}$ & $\begin{array}{l}24.97 \\
25.45\end{array}$ & 50.42 & 25.21 & 1271.20 & 0.1152 \\
\hline 4. & $\begin{array}{l}4 \mathrm{~A} \\
4 \mathrm{~B}\end{array}$ & $\mathrm{Y}_{4}$ & $\begin{array}{l}19.39 \\
19.09\end{array}$ & 38.48 & 19.24 & 740.40 & 0.045 \\
\hline 5 & $\begin{array}{l}5 \mathrm{~A} \\
5 \mathrm{~B}\end{array}$ & $Y_{12}$ & $\begin{array}{l}22.13 \\
21.43\end{array}$ & 243.56 & 21.78 & 948.98 & 0.245 \\
\hline 6 & $\begin{array}{l}6 \mathrm{~A} \\
6 \mathrm{~B}\end{array}$ & $Y_{13}$ & $\begin{array}{l}25.43 \\
26.77\end{array}$ & 52.20 & 26.10 & 1363.32 & 0.8978 \\
\hline 7 & $\begin{array}{l}7 \mathrm{~A} \\
7 \mathrm{~B}\end{array}$ & $\mathrm{Y}_{14}$ & $\begin{array}{l}34.20 \\
37.40\end{array}$ & 71.60 & 35.80 & 2568.40 & 5.12 \\
\hline 8 & $\begin{array}{l}8 \mathrm{~A} \\
8 \mathrm{~B}\end{array}$ & $Y_{23}$ & $\begin{array}{l}25.54 \\
21.82\end{array}$ & 47.36 & 23.68 & 1128.40 & 6.9192 \\
\hline 9 & $\begin{array}{l}9 \mathrm{~A} \\
9 \mathrm{~B}\end{array}$ & $\mathrm{Y}_{24}$ & $\begin{array}{l}28.9 \\
27.4\end{array}$ & 56.30 & 28.15 & 1585.97 & 1.125 \\
\hline 10 & $\begin{array}{l}10 \mathrm{~A} \\
10 \mathrm{~B}\end{array}$ & $\mathrm{Y}_{34}$ & $\begin{array}{l}26.36 \\
25.22\end{array}$ & 51.58 & 25.79 & 1330.90 & 0.6498 \\
\hline 11 & $\begin{array}{l}11 \mathrm{~A} \\
11 \mathrm{~B}\end{array}$ & $\mathrm{C}_{1}$ & $\begin{array}{l}20.80 \\
22.76\end{array}$ & 43.56 & 21.78 & 950.66 & 1.9208 \\
\hline 12 & $\begin{array}{l}12 \mathrm{~A} \\
12 \mathrm{~B}\end{array}$ & $\mathrm{C}_{2}$ & $\begin{array}{l}30.58 \\
28.92\end{array}$ & 59.50 & 29.75 & 1771.50 & 1.3778 \\
\hline 13 & $\begin{array}{l}13 \mathrm{~A} \\
13 \mathrm{~B}\end{array}$ & $\mathrm{C}_{3}$ & $\begin{array}{l}24.35 \\
22.41\end{array}$ & 46.76 & 23.38 & 1095.13 & 1.8818 \\
\hline 14 & $\begin{array}{l}14 \mathrm{~A} \\
14 \mathrm{~B}\end{array}$ & $\mathrm{C}_{4}$ & $\begin{array}{l}16.17 \\
17.97\end{array}$ & 34.14 & 17.07 & 584.38 & 1.62 \\
\hline
\end{tabular}

å $S_{i}^{2}=74.18$

Therefore

$$
\text { Replication variance, } \mathrm{S}_{\mathrm{y}}{ }^{2}=\frac{74.18}{14}=5.30
$$

Replication, Error, $\mathrm{S}_{\mathrm{y}}=\sqrt{5.30}=2.30$

Fishers test

The test of adequacy was performed using fishers test. The computations for Fishers test of Adequacy, are presented in Table 7.

Table 7 :Computations for Fisher's Test of Adequacy

\begin{tabular}{|l|l|l|l|l|l|l|}
\hline $\begin{array}{l}\text { Response } \\
\text { symbol }\end{array}$ & $\begin{array}{l}\mathbf{Y}_{\mathbf{e}} \\
\left(\mathbf{Y}_{\text {exp }}\right)\end{array}$ & $\begin{array}{l}\mathbf{Y}_{\mathbf{p}} \\
\left(\mathbf{Y}_{\text {pred }}\right)\end{array}$ & $\mathbf{Y}_{\mathrm{e}}-\bar{Y}_{e}$ & $\mathbf{Y}_{\mathbf{p}}-\bar{Y}_{p}$ & $\left(\mathbf{Y}_{\mathrm{e}}-\bar{Y}_{e}\right)^{\mathbf{2}}$ & $\left(\mathbf{Y}_{\mathbf{p}}-\bar{Y}_{p}\right)^{\mathbf{2}}$ \\
\hline $\mathrm{C} 1$ & 22.98 & 27.08 & 0.13 & 3.727 & 0.0169 & 13.8905 \\
\hline $\mathrm{C} 2$ & 26.75 & 23.93 & 3.90 & 0.577 & 15.21 & 0.332929 \\
\hline $\mathrm{C} 3$ & 22.88 & 22.71 & 0.03 & -0.643 & 0.0009 & 0.413449 \\
\hline $\mathrm{C} 4$ & 18.79 & 19.69 & -4.06 & -3.663 & 16.4836 & 13.4176 \\
\hline $\mathbf{a}$ & 91.40 & 93.41 & \multicolumn{7}{|l|}{} & 31.7114 & 28.0545 \\
\hline Mean & $\mathbf{2 2 . 8 5}$ & $\mathbf{2 3 . 3 5 3}$ & \multicolumn{7}{|l|}{} & \\
\hline
\end{tabular}

$$
\begin{aligned}
& \mathrm{S}_{\exp }^{2}=\stackrel{\circ}{\mathrm{a}} \quad\left(Y_{e}-\bar{Y}_{e}\right)^{2} /(\mathrm{N}-1)=31.7114 /(4-1)=10.570467 \\
& \mathrm{~S}_{\text {pred }}^{2}=\stackrel{\circ}{\mathrm{a}} \quad\left(Y_{p}-\bar{Y}_{p}\right)^{2} /(\mathrm{N}-1)=28.0545 /(4-1)=9.35
\end{aligned}
$$

Using $\mathrm{S}_{\exp }^{2}$ as $\mathrm{S}_{1}^{2}$ and $\mathrm{S}_{\text {pred }}{ }^{2}$ as $\mathrm{S}_{2}{ }^{2}$ in in Fisher's test equation, then, 


$$
\mathrm{F}=\frac{S_{1}^{2}}{S_{2}^{2}}=10.5705 / 9.3500=1.13
$$

And from Fisher's Table,

$$
F_{a(3,3)}=9.28 \text { and } \frac{1}{F}=0.108
$$

Since, Fisher's condition, $\frac{1}{F}<\mathrm{S}_{1}{ }^{2} / \mathrm{S}_{2}{ }^{2}<\mathrm{F}$ is satisfied, the Null Hypothesis, $\mathrm{H}_{0}$, is also accepted. And so there is no significant difference between the predicted and experimentl results.

\subsection{Predicted Costs and mix ratios}

The costs and mix ratios corresponding to concrete with an elastic modulus of $36 \mathrm{~N} / \mathrm{Mm}^{2}$ is given below.

Table 6: Concrete mix ratios and costs corresponding to elastic modulus of $36 \mathrm{~N} / \mathrm{mm}^{2}$

\begin{tabular}{|l|l|l|l|l|}
\hline S/N & $\begin{array}{l}\text { Elastic } \\
\text { modulus } \\
\text { Y(N/mm }\end{array}$ & $\begin{array}{l}\text { Mix Ratios } \\
\text { w/c }: \text { C:FA:CA }\end{array}$ & $\begin{array}{l}\text { Market- } \\
\text { based } \\
\text { Costs } \\
(\mathrm{N})\end{array}$ & $\begin{array}{l}\text { Predicted } \\
\text { Costs }\end{array}$ \\
\hline 1 & 36 & $0.64: 1.00: 2.58: 5.98$ & $19,602.98$ & $19,596.72$ \\
\hline 2 & 36 & $0.56: 1.00: 2.00: 3.07$ & $22,545.88$ & $22,560.73$ \\
\hline 3 & 36 & $0.51: 1.00: 1.62: 1.85$ & $25,528.03$ & $25,536.19$ \\
\hline 4 & 36 & $0.50: 1.00: 1.52: 1.42$ & $26,927.58$ & $26,915.23$ \\
\hline 5 & 36 & $0.49: 1.00: 1.30: 1: 07$ & $29,076.89$ & $29,082.58$ \\
\hline 6 & 36 & $0.47: 1.00: 0.95: 1.24$ & $30,577.78$ & $30,639.44$ \\
\hline
\end{tabular}

where $\mathrm{w} / \mathrm{c}=$ water - cement ratio

$$
\begin{aligned}
\mathrm{C} & =\text { cement } \\
\text { F.A } & =\text { Fine aggregate } \\
\text { C.A } & =\text { Coarse aggregate }
\end{aligned}
$$

A cursory look at Table 6 shows that the maximum percentage difference between the market-based costs and the predicated costs, is $0.07 \%$. And, the optimum mix and cost of concrete with an elastic modulus of $36 \mathrm{~N} / \mathrm{mm}^{2}$ are 0.64:1.00:2.58:5.98 and $\mathrm{N} 19,596.72$ respectively.

\section{Conclusions}

An optimization model based on Osadebe theory has been successfully formulated for the determination of cost estimates of concrete based on its elastic modulus. In doing so, the first things to be calculated are the proportions that can yield a given elastic modulus, and subsequently estimates of the costs of the predicted mix proportions, are obtained.

Conversely, the model can be used to predict the elastic modulus, E, obtainable from concrete mixture of a given cost and comprehensive strength.

The model can be used to determine optimum concrete mix and its cost based on its elastic modulus. The maximum elastic modulus predictable by the model is $50.04 \mathrm{~N} / \mathrm{mm}^{2}$ and the cheapest mix proportion that yield it, is 0.55: 1.0:2.0:3.0 with a total cost of $\mathrm{N} 22,387.78$.

\section{References.}

[1] BS 1881, Part 118(1983), "Method of determination of Static modulus of elasticity in compression". BSI-London.

[2] BS 12(1983), "Specification for Portland cement". BSI-London.

[3] BS 812 Part 103(1983), "Method of determination of particle size distribution". BSI- London.

[4] BS 5328, Part 2(1997), "Methods of specifying concrete mixes". BSI-London.

[5] Conrad, M., Anfleger, M. and Malkawi, A.I.H., (2007). "Investigating the Modulus of Elasticity of Young RCC". 6th Annual meeting symposium, erman research, Muanchu, Germany.

[6] Egbulonu, R.B.A.(2011) "Optimization model for predicting the Modulus of Elasticity and Flexural Strength of Concrete. "Unpublished M.Engr Project of the Department of Civil Engineering, Federal University of Technology, Owerri,Nigeria.

[7] Majid, K. I(1974). "Optimum Design of Structures, Butter worth and company, London.

[8] Osadebe, N.N., 2003, “Generalized Mathematical Modeling of Compressive Strength of Normal Concrete as a Multi-Variant function of the properties of its Constituent Components". A paper delivered at the College of Engineering. University of Nigeria, Nsukka.

[9] Sanders, P., (2007) "Basic Approaches to Optimization Problems". College of Information Sciences and Technology, Pennsylvanian state University. Available from <http//www.google.com./search $>$

[10] Simon, M. J; Laggeragren,.E.S; Snyder,K.A(1997). "Concrete mixture optimization using statistical Mixture Design methods". Proceeding of PCI/FHWA. International Symposium on High Performance Concrete, New Orleans, pp 230-244. 